\title{
Development of Serotonin-Induced lon Currents in Identified Embryonic Retzius Cells from the Medicinal Leech (Hirudo medicinalis)
}

\author{
V. Lessmann and I. D. Dietzel \\ Department of Neurophysiology, Max Planck Institute for Psychiatry, D-8033 Planegg-Martinsried, Germany
}

Retzius cells and the cutaneous baroreceptive P-cells of adult medicinal leeches (Hirudo medicinalis) respond to 5-HT by $\mathrm{Cl}$ as well as by monovalent cation conductances (Drapeau et al., 1989). However, chemical synaptic connections between Retzius cells (Liu and Nicholls, 1989) as well as Retzius cells and P-cells in culture (Drapeau and SanchezArmass, 1988) are mediated by postsynaptic $\mathrm{Cl}^{-}$currents in response to 5-HT release from the presynaptic cell.

It was the aim of the present study to find out whether the response, which has been shown to be involved in synaptic transmission or whether the cation current, which has so far only been observed upon extrasynaptic 5-HT application, dominates during embryogenesis. Currents induced by transmitter application with a fast perfusion system were measured with a single-electrode voltage clamp and patch pipettes in whole-cell configuration. Control experiments, performed on Retzius cells from adult leeches after $1 \mathrm{~d}$ in culture, showed $\mathrm{Cl}^{-}$currents in response to 5-HT application in all cells investigated. Ninety percent of the cells tested showed additional 5-HT-elicited $\mathrm{Na}^{+}, \mathrm{K}^{+}$, or both currents. However, the conductance of cation currents amounted only to $10 \%$ of the $\mathrm{Cl}^{-}$currents.

Embryonic Retzius cells were identified in dissociated cultures by their violet-blue fluorescence acquired by preincubation of intact ganglia or embryos in culture medium containing the autofluorescent 5-HT analog 5,7-dihydroxytryptamine. The first responses to 5-HT were measured at embryonic day $10(E 10)$, after voltage-activated $\mathrm{Ca}^{2+}$ and $\mathrm{Na}^{+}$currents had already developed. 5-HT application induced exclusively $\mathrm{Cl}^{-}$currents until E16. This suggests that the receptor-channel complex, which also mediates synaptic responses, is expressed first in measurable quantities. Hence, there is currently no indication that extrasynaptic receptors dominate in immature cells in this preparation.

Specific synapse formation requires incorporation of transmitter receptors and selection of the appropriate receptor-gated ion

\footnotetext{
Received Aug. 1, 1990; revised Oct. 15, 1990; accepted Oct. 23, 1990.

This work was supported by the Deutsche Forschungsgemeinschaft (SFB 220A1). We wish to thank $K$. Gottmann for many valuable suggestions, especially concerning the protocol for staining of Retzius cells. Staging of leech embryos older than E12 was initially started in collaboration with L. D. Leake. We also want to thank V. Bulka for technical assistance, C. Parsons for critically reading the manuscript, and H. D. Lux for helpful discussions.

Correspondence should be addressed to I. D. Dietzel, Max-Planck-Institut für Psychiatrie, Abteilung Neurophysiologie, Am Klopferspitz 18A, D-8033 Martinsried, Germany
}

Copyright (C) 1991 Society for Neuroscience $0270-6474 / 91 / 110800-10 \$ 03.00 / 0$ channels in the postsynaptic membrane. Questions not yet fully answered are when during embryogenesis these ion channels are expressed and whether they are modified during further development. In 2 preparations, where the development of transmitter-activated ion conductances could be followed through different stages of embryogenesis in neurons, no changes in the ion selectivity of the transmitter-activated ion currents have been reported [GABA and $\mathrm{ACh}$ responses in dorsal unpaired median (DUM) neurons of the grasshopper, Goodman and Spitzer, 1979, 1980; GABA responses in Rohon-Beard neurons of Xenopus, Bixby and Spitzer, 1982]. However, it may be of relevance that these cells displayed only 1 type of response to the transmitter of interest during the entire time span investigated.

Two types of $\mathrm{ACh}$ receptors, one mediating synaptic responses and a second dominating in embryogenesis and upon denervation, have been extensively studied at neuromuscular end plates (for reviews, see Schuetze and Role, 1987; Brehm and Henderson, 1988). These have been shown to differ in the expression of a subunit of the channel (Mishina et al., 1986), leading to larger amplitudes and faster inactivation kinetics of ACh responses in more mature, innervated cells.

Two types of receptors to 1 agonist (5-HT) have also been described in the pressure-sensitive neuron (P-cell) and the Retzius cell of the leech, where somatic administration of 5-HT has been found to elicit a $\mathrm{Cl}$ current and an additional, smaller monovalent cation current (Drapeau et al., 1989). It has been suggested that both currents are activated by distinct receptors coupled to different second-messenger pathways. While $\mathrm{Cl}^{-}$ channels are activated by a receptor distinct from the mammalian subtypes via cAMP-dependent protein kinase $\mathrm{A}$, cation channels appear to be activated by $5-\mathrm{HT}_{2}$ receptors by means of protein kinase C (Sanchez-Armass et al., in press). In cultured Retzius-P-cell pairs, the postsynaptic response of the P-cell has been shown to be carried by the $\mathrm{Cl}^{-}$current. The cation currents, which were only elicited by application of exogenous 5-HT to the somata of the P-cells and were thus regarded as extrasynaptic, were downregulated upon contact to the presynaptic Retzius cell (Drapeau and Sanchez-Armass, 1988; Drapeau et al., 1989). Hence, it seemed worthwhile to investigate whether, in analogy to the findings at the neuromuscular end plate, extrasynaptic receptors are also dominantly expressed during early embryogenesis and downregulated by contact to the presynaptic cell in the course of maturation.

So far, it has not been possible to unambiguously identify and isolate embryonic P-cells. However, staining with the autofluorescent dye 5,7-dihydroxytryptamine (5,7-DHT) allowed us to investigate 5-HT-induced currents in identified embryonic Ret- 
zius cells of dissociated ganglia under single-electrode voltage clamp. Adult Retzius cells in culture are able to form mutual inhibitory chemical synapses as well (Fuchs et al., 1981; Henderson et al., 1983; Kuffler et al., 1987), which, as for postsynaptic P-cells, are reversed by $\mathrm{Cl}^{-}$injection into the postsynaptic cell (Liu and Nicholls, 1989). In Retzius cells of the horse leech Heamopis sanguisuga, $\mathrm{Cl}^{-}$-dependent spontaneous IPSPs, blockable by 5 -HT antagonists, have been observed (Smith et al., 1975). Therefore, there is good evidence that, at postsynaptic Retzius cells, like at postsynaptic P-cells (Fuchs et al., 1982; Drapeau and Sanchez-Armass, 1988; Drapeau et al., 1989), the $\mathrm{Cl}^{-}$channels are the mediators of the synaptic responses. Hence, it seemed useful to investigate, in Retzius cells, whether any changes in the relative expression of both currents occur during embryogenesis.

\section{Materials and Methods}

Cell cultures from adult Retzius cells. Adult leeches were obtained from H. Hendriks, D-5540 Prüm or Ricarimpex, F-33980 Audenge. Retzius cells were identified by their characteristic size and position within the segmental ganglia and were removed after opening the ensheathing capsules. Because the neuritic network deteriorated space-clamp conditions in adult as well as embryonic neurons, single cells were isolated to remove the neurites and were transferred into culture dishes. This treatment also facilitated complete perfusion of the cells and eliminated synaptic input. Most cells were investigated after $1 \mathrm{~d}$ in culture, which was the time needed for the incubation procedure to identify embryonic cells and the cells to sufficiently attach to the recording dishes (see below). For control purposes, some adult cells were additionally investigated after up to $10 \mathrm{~d}$ in culture. Procedures for removal of the cells and culture conditions were essentially the same as those originally worked out by Ready and Nicholls (1979). The cells were aspirated into approximately $100-\mu$ m-diameter pipettes following treatment with collagenase/dispase $(2 \mathrm{mg} / \mathrm{ml})$ in culture medium, as described by Dietzel et al. (1986). In some experiments, cells were also removed without enzymatic treatment. These cells were plucked out of the opened ganglia by seizing the unipolar axon stump as close as possible to the neuropil using extremely fine, sharpened Dumont forceps. The isolated cells were then washed several times in sterile culture medium [Leibowitz L15, supplemented with $6 \%$ heat-inactivated fetal calf serum (FCS; Gibco), glucose $(6 \mathrm{mg} / \mathrm{ml})$, and gentamycin $(0.1 \mathrm{mg} / \mathrm{ml})]$ and plated on polyDL-lysine- (PDL; $2.5 \mathrm{mg} / 100 \mathrm{ml}$ ) coated Petri dishes $(3.5 \mathrm{~cm})$. After adhesion of the cells in medium without serum, FCS was added to a final concentration of $6 \%$, if the cells were kept for more than $1 \mathrm{~d}$ in culture.

Cell cultures, staging, and identification of embryonic Retzius cells. Leech embryos were obtained from a breeding colony maintained in the laboratory, following essentially the protocol of Fernández and Stent (1982). Cocoons were collected every second day. They were kept in humid containers at $24^{\circ} \mathrm{C}$. After opening a cocoon, embryos were removed into artificial spring water (Muller et al., 1981, p. 251). Because intracocoon development depends critically on temperature of incubation, the age of the embryos was determined according to the following morphological criteria: embryonic day 9 (E9), formation of the 32 ganglia in the middle of the germinal plate completed, but no sign of fusion of the 7 caudalmost ganglia to the tail ganglion; no sign of formation of the caudal sucker (Fig. 1A; Fernández and Stent, 1982, their Fig. 6). E10, at the location of the future caudal sucker, a small incision becomes visible in the germinal plate (see Dietzel and Gottmann, 1988, their Fig. $2 A$ ). E11, at the caudal end of the germinal plate, a disklike structure appears, which gives rise to the future caudal sucker (Fig. $1 B$; Fernández and Stent, 1982, their Fig. 7), and in addition, first signs of lateral blood sinuses can be seen at higher magnification (Dietzel and Gottmann, 1988, their Fig. 3A). E12, germinal plate extends further caudally and encapsulates up to half of the larval body; tail formation starts at the position of the caudal sucker, such that the embryo arches rostrally to the larval tail (Fig. 1C). E13-14, the germinal plate extends $2 / 3$ around the larval body; its edges have met and sealed at the dorsal midline at the location of the first ganglia. The caudal sucker is now located near the larval end, leaving a small stump of larval body, still filled with the yolk, that the larva ingested during the first days of intracocoon de-
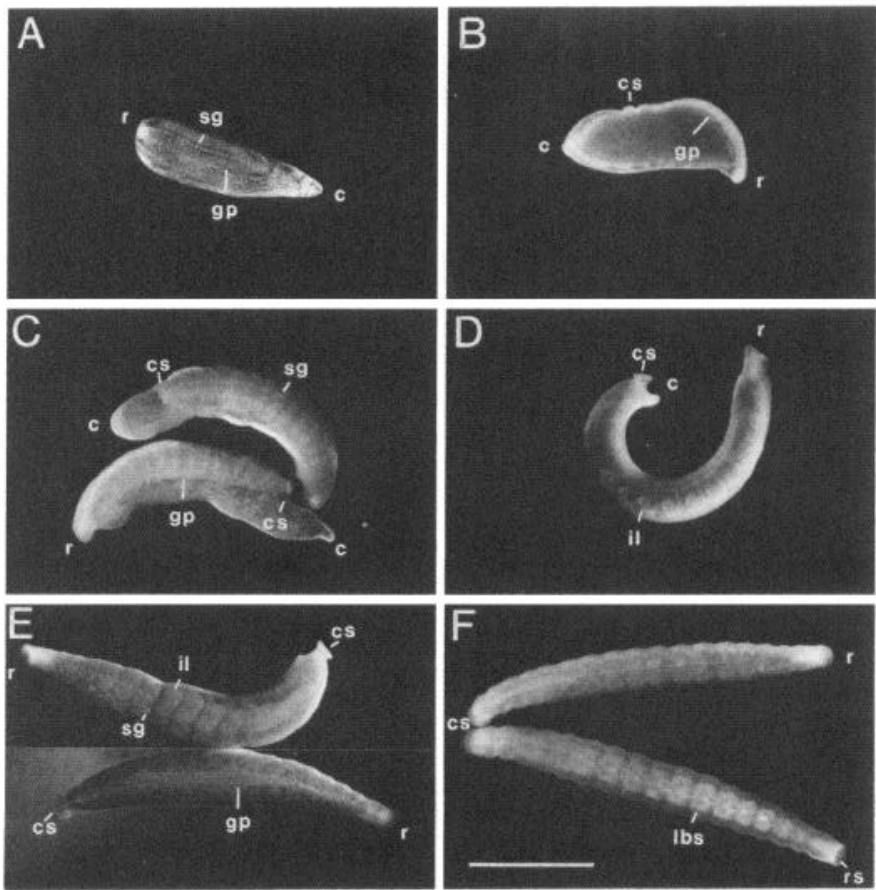

Figure 1. Morphological development of Hirudo medicinalis between E9 and E16. $A$, E9. Formation of germinal plate $(g p)$ and segmental ganglia $(s g)$ is completed. Rostral end $(r)$, to the left; caudal end $(c)$, to the right. $B$, E11. Caudal sucker $(c s)$ is visible at the caudal end of the germinal plate. $C$, E12. Tail formation starts at caudal sucker (cs). $D$, E13-14. Germinal plate is extended to near caudal end $(c)$. First signs of intestinal lobes (il) are seen. $E$, E15. Caudalmost intestinal lobes are fully elongated, and dorsal midline is still open (lower embryo). F, E16. Lateral blood sinus (lbs) is visible, and dorsal midline is closed (upper embryo). rs, rostral sucker. For detailed description, see Materials and Methods. Scale bar, $5 \mathrm{~mm}$.

velopment (Fig. 1D). Eyespots appear but are not yet pigmented. Structures of the future intestinal lobes are visible, but the caudalmost bilaterally paired gut ceca have not yet fully elongated (for further illustrations of the morphological development of the intestinal lobes, see Leuckart, 1886). E15, the germinal plate encloses most of the body (Fig. $1 E$ ), a small remaining yolk tail near caudal sucker is just visible, the caudalmost gut ceca have acquired their final length, and the 10 eyespots become pigmented. E16, the germinal plate has encircled the body and has fused at the dorsal midline; the tail sucker is not yet used (Fig. $1 F$ ). E17, the body wall has sealed, the tail sucker is used, the dorsal blood sinus appears, and the lateral blood sinuses can clearly be seen filled with red blood. E18 to hatching (ca. 10 days later), pigmentation of the skin develops, all tissues become stouter, and formation of intestines is completed.

Because of the small size of the cells $(<30 \mu \mathrm{m})$ and the ganglia (ca. $200 \mu \mathrm{m}$ ), embryonic Retzius cells could not easily be identified and removed following the procedure used in adult leeches. Therefore, embryonic Retzius cells were identified in dissociated cultures after incubating embryonic ganglia with the autofluorescent 5-HT analog 5,7dihydroxytryptamine (5,7-DHT): Small incisions were made into the skin of embryos younger than E12 to facilitate uptake of 5,7-DHT. The embryos were then incubated for $12 \mathrm{hr}$ at room temperature in a solution containing L15 with enhanced FCS $(12 \%)$, 5,7-DHT $(300 \mu \mathrm{M})$, the MAO-inhibitor iproniazid $(40 \mu \mathrm{M})$, and ascorbic acid $(25 \mu \mathrm{M})$ as antioxidant (Lessmann et al., 1990). The access of light to the preparation was minimized to avoid possible light-dependent autoxidation of 5,7DHT. Ganglion chains were then dissected out and placed on PDLcoated coverslips. Fluorescence of cells showing staining with maximum emission wavelength of $420 \mathrm{~nm}$ (Silva et al., 1988) was tested with the filter combination of BP 365, FT 390, LP 397 (Zeiss).

Embryos older than E1 2 moved too much to allow careful incisions of the skin. Thus, the ganglion chains were removed with fine forceps after mounting the embryos ventral side up in Sylgard-coated Petri dishes filled with culture medium. Segmental ganglion chains were then 


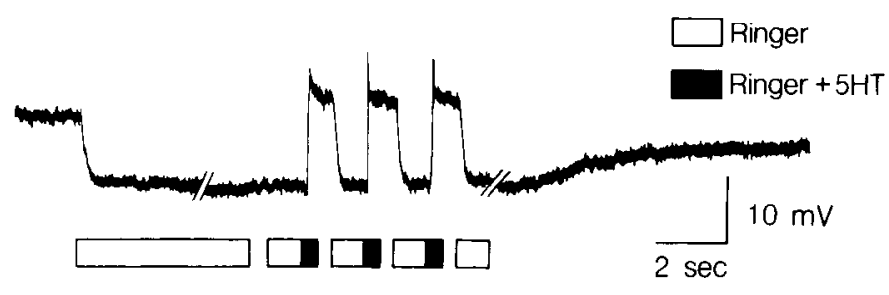

Figure 2. Voltage response of an embryonic neuron to switching of external perfusion solutions. Cell was bathed in Ringer's solution. At the time indicated by the first white bar, the cell hyperpolarized, due to application of the same Ringer's solution by gravity-driven flow. Turning on the Ringer's perfusion for a second time after a short interruption did not elicit another hyperpolarization. Switching back and forth between Ringer's solution and a second channel containing 5-HT (200 $\mu \mathrm{M}$ ) in addition (black bars) elicited reproducible depolarizations. Several seconds after turning off the perfusion, the original membrane potential of $-50 \mathrm{mV}$ recovered.

placed on PDL-coated glass coverslips covered with L15. After attachment of the ganglion chains, gentamycin $(0.1 \mathrm{mg} / \mathrm{ml})$, glucose $(6 \mathrm{mg} /$ $\mathrm{ml}$ ), and FCS (10\%) were added. After incubation for $12 \mathrm{hr}$ in this solution, 5,7-DHT (300 $\mu \mathrm{M})$, iproniazid ( $40 \mu \mathrm{M})$, and ascorbic acid (25 $\mu \mathrm{M}$; all final concentrations) were added. Following further incubation for $4 \mathrm{hr}$, coverslips were inspected under the fluorescence microscope.

Following confirmation of staining of the Retzius cells, the incubation was continued after adding $2 \mathrm{mg} / \mathrm{ml}$ collagenase/dispase (Boehringer Mannheim) and raising the $\mathrm{Mg}^{2+}$ concentration to $40 \mathrm{mM}$ (to prevent possible $\mathrm{Ca}^{2+}$-dependent 5,7-DHT release). After $1-1.5 \mathrm{hr}$, the ganglia were dissociated by trituration with fine fire-polished glass pipettes of decrcasing tip diametcr $(150-80 \mu \mathrm{m})$. Cells were then plated on PDLcoated Petriperm dishes (Bachhofer), which passed sufficient light at 365 $\mathrm{nm}$ to allow selection of the cells under an inverted fluorescence microscope (Zeiss Axiovert 35).

Recordings. Recordings were made with a single-electrode voltageclamp amplifier (SEC01, NPI-Instruments; R. Polder, D-7146 Tamm), operated at switching frequencies of $20-30 \mathrm{kHz}$ for embryonic and 6$10 \mathrm{kHz}$ for adult cells. To decrease the electrode resistance and to allow better control of the internal solutions, suction (patch) electrodes, manufactured from Duran glass with a 2-step pulling procedure (Mecanex Puller, Geneva), were used. The most commonly employed internal solution contained (in $\mathrm{mM}$ ) $\mathrm{K}^{+}, 133$; gluconate, 132; HEPES, 20; and EGTA, $10(\mathrm{pH}, 7.3)$. Osmolarity was adjusted with glucose to 300 mOsm (InK solution). To mimic physiological conditions in some experiments, a filling solution named InP was used, which contained (in тм) $\mathrm{Na}^{+}, 10 ; \mathrm{K}^{+}, 129 ; \mathrm{Cl}^{-}, 20 ; \mathrm{N}$-methyl-D-glucamine (NMDG), 26; gluconate, 128; HEPES, 20; and EGTA, $10(\mathrm{pH}, 7.3)$. Osmolarity was adjusted to 300 mOsm with glucose. To allow exclusive permeation of $\mathrm{Cl}^{-}$ions in some experiments, $\mathrm{InCl}$ was used, which contained (in $\mathrm{mM}$ ) Cl , 127; NMDG, 165; HEPES, 20; and EGTA, 10 (pH, 7.3). Osmolarity was adjusted to $300 \mathrm{mOsm}$ with glucose. With these filling solutions, the initial resistances of the electrodes amounted to 5-10 M 2 . The series resistance, which could be 2-3 times higher during recording, had no influence on the discontinuous potential registration of the amplifier.

The formation of the seal (ca. $1 \mathrm{G} \Omega$ ) and rupture of the membrane by suction were monitored by application of small voltage pulses in the voltage-clamp mode. Drugs and external solutions of defined composition were delivered from a multibarreled perfusion pipette (Carbone and Lux, 1987), which was positioned at a distance of approximately $200 \mu \mathrm{m}$ from the cell, allowing a fast exchange of the entire solution surrounding the cell. The flow was switched from one channel to the other by triggerable, pneumatically operated high-speed valves (Festo K.G., L Esslingen, D-7300) as described by Davies et al. (1988).

Turning on the perfusion channel containing bath solution regularly resulted in a hyperpolarization by $1-10 \mathrm{mV}$ (Fig. 2) or in an activation of an outward current under voltage clamp. However, because this "flow-induced" response was only elicited by the first application of the perfusion solution and did not reappear when the flow was interrupted for a short time or when solutions were switched between different barrels, drug effects could be studied reliably. Several seconds after switching off the perfusion, the membrane potential slowly recovered to original values (Fig. 2), and the "flow-induced" response could be evoked again. Similar responses have also been observed in other cultured cells using the same perfusion method (Misgeld and Dietzel, 1989). They could result either from the removal of an unstirred layer containing, for instance, a slightly higher $\mathrm{K}^{+}$concentration directly at the membrane or from the opening of stretch-activated channels (see, e.g., Blackshaw and Thompson, 1988; Medina and Bregestovski, 1988). Stretch-activated single channels with preferential $\mathrm{K}^{+}$selectivity have recently also been described in Retzius cells of Hirudo medicinalis (Pellegrino et al., 1990).

To obtain maximal responses in developing neurons and to reveal any desensitization not normally seen with concentration changes that are too slow, $200 \mu \mathrm{M} 5-\mathrm{HT}$ was used in all experiments. This concentration slightly exceeds the $150 \mu \mathrm{M}$ described by Sunderland et al. (1980) and the $100 \mu \mathrm{M}$ reported by Drapeau and Sanchez-Armass (1988) to provoke maximum responses. To test the ion selectivity of the transmitter-activated channels, 5-HT was added to external solutions of different compositions (in mm): ExNa: $\mathrm{Na}^{+}, 80 ; \mathrm{Ca}^{2+}, 1.8 ; N$-methyl-Dglucamine (NMDG), 100; gluconate, 84; sulfate, 50; and HEPES, 20. ExK: $\mathrm{K}^{+}, 4 ; \mathrm{Ca}^{2+}, 1.8$; NMDG, 180; gluconate, 4; sulfate, 84; and HEPES, 20. ExCl: $\mathrm{Cl}^{-}, 156$; $\mathrm{Ca}^{2+}, 1.8 ;$ NMDG, 180; and HEPES, 20. All external solutions were titrated to $\mathrm{pH} 7.3$, using $\mathrm{H}_{2} \mathrm{SO}_{4}$ for ExNa and ExK; for $\mathrm{ExCl}$, the final concentration of $156 \mathrm{mM} \mathrm{Cl}^{-}$was a result of adjusting the $\mathrm{pH}$ with $\mathrm{HCl}$. Osmolarity was adjusted to that of the culture medium with glucose (L15 with gentamycin, glucose, and 6\% FCS; 330 mOsm). To obtain better seals, the culture medium was exchanged for Ringer's solution (in mM; $\mathrm{Na}^{+}, 115 ; \mathrm{K}^{+}, 4 ; \mathrm{Cl}, 117 ; \mathrm{Ca}^{2+}, 1.8 ; \mathrm{NMDG}, 35$; gluconate, 35; and Tris, 20; adjusted to an osmolarity of $330 \mathrm{mOsm}$ and $\mathrm{pH} 7.3$ with glucose and $\mathrm{HCl}$ ) immediately prior to the experiments. All external solutions contained the same concentration of $\mathrm{Ca}^{3+}$, which was beneficial in maintaining stable seals.

Some of the data were recorded on a Racal Store 4 tape recorder after filtering at $1 \mathrm{kHz}$ and displayed on a Hewlett Packard chart recorder. Most of the data were directly digitized on a PDP $11 / 23$ computer with a digitizing rate of 350 or $700 \mathrm{~Hz}$ and stored on a hard disk. Data collection and evaluation were performed with the programs INTESV and AUTESV written by $\mathrm{H}$. Zucker.

\section{Results}

Adult cells. Retzius cells in vivo as well as in vitro respond to 5-HT application with a hyperpolarizing $\mathrm{Cl}^{-}$current (Walker and Smith, 1973; Cemerikic et al., 1985). In addition, there is evidence for a second 5-HT receptor, mediating an initial small depolarization (Erwin and Thies, 1975; Smith and Walker, 1975) by flow of monovalent cations (Drapeau et al., 1989).

At first, we determined the amplitudes of both currents with the same experimental configuration as later used for the characterization of the embryonic responses. Using a pipette solution, which approximated the presumed physiological composition (InP), and with 5-HT added to Ringer's solution, currents were observed that reversed at $-47 \pm 6 \mathrm{mV}(n=5$; data not shown). The calculated reversal potential for $\mathrm{Cl}^{-}$was $-44 \mathrm{mV}$. In experiments where the internal solution contained only $\mathrm{Cl}$ as possible permeant ion ( $\mathrm{InCl}$ ) and 5-HT was applied in Ringer's solution, the reversal potential was $-15 \pm 4 \mathrm{mV}(n=5$; $E_{\mathrm{c} 1}=+2 \mathrm{mV}$; see e.g., Fig. 3). If $\mathrm{Na}^{+}$and $\mathrm{K}^{+}$were omitted from the external solution $(\mathrm{ExCl})$, the reversal potential of the current shifted slightly to the left to an average of $-20 \pm 5 \mathrm{mV}(n=$ 5; $E_{\mathrm{Cl}}=-5 \mathrm{mV}$ ). This shift in measured reversal potential by $5 \mathrm{mV}$ parallels the shift in the calculated reversal potential by $7 \mathrm{mV}$, which is due to the smaller $\mathrm{Cl}^{-}$concentration in the Ringer's solution as compared to ExCl. With high $\mathrm{Cl}^{-}$in the pipette, for both extracellular solutions, the reversal potential was about $15 \mathrm{mV}$ more negative than the calculated $\mathrm{Cl}^{-}$equilibrium potentials in adult cells. This deviation could be explained by assuming that the intracellular $\mathrm{Cl}^{-}$concentration in the cell amounted to only 64-70 $\mathrm{mm}$ due to incomplete exchange between the pipette solution and the cell interior. While $\mathrm{K}^{+}$was exchanged against $\mathrm{Cs}^{+}$within $5 \mathrm{~min}$ after opening the cells using 
2 similar patch electrodes (D. Bruns, personal communication), it is surprising that intracellular $\mathrm{Cl}^{-}$should have risen to only half of the pipette concentration. However, a possible explanation is that intracellular negative charges, which are bound predominantly to less mobile proteins, are only partially exchangeable for $\mathrm{Cl}^{-}$in these large cells (diameters, about $80 \mu \mathrm{m}$ ). When an intracellular $\mathrm{Cl}^{-}$concentration in the physiological range was used (InP solution; see above), the reversal potential deviated only $3 \mathrm{mV}$ from the calculated $E_{\mathrm{C}}$. In experiments where the internal solution contained no $\mathrm{Cl}^{-}$(InK), the physiologically present $\mathrm{Cl}^{-}$ions were washed out completely within several minutes, as seen by the disappearance of residual 5-HTinduced $\mathrm{Cl}^{-}$currents.

In the case of a significant contribution of monovalent cations to the 5-HT-mediated response, the reversal potential for the combination InCl/Ringer's should be shifted to positive potentials relative to InCl/ExCl. Because the measured shift did not exceed the calculated shift in $E_{\mathrm{Cl}}$, these results confirm the finding that Retzius cells respond to 5-HT application predominantly by $\mathrm{Cl}$ currents (Walker and Smith, 1973; Čemerikić et al., 1985). With $\mathrm{Cl}^{-}$in external and internal solutions, currentvoltage relationships were approximately linear around the reversal potential, and slope conductances could be evaluated. Calculated slope conductances were $36 \pm 20 \mathrm{nS}$ (mcan $\pm \mathrm{SD}$; $n=5)$ using solutions with exclusively $\mathrm{Cl}^{-}$as the permeant ion (InCl, FxCl), $38 \pm 22 \mathrm{nS}(n=5)$ employing InCl/Ringer's solutions, where $\mathrm{K}^{+}$and $\mathrm{Na}^{+}$could additionally flow into the cells, and $42 \pm 17 \mathrm{nS}(n=5)$ in solutions where, in addition to $\mathrm{Cl}^{-}$, $\mathrm{K}^{+}$and $\mathrm{Na}^{+}$could flow in both directions (InP, Ringer's). In the case of a significant contribution of cation currents, again, changes in the conductance would have been expected.

The calculated slope conductances correspond well to the value of $43 \pm 5.7 \mathrm{nS}$ reported by Drapeau et al. (1989) for the $\mathrm{Cl}^{-}$ conductance of adult Retzius cells in culture, measured with conventional microelectrodes.

In the following experiment, cells were tested for a possible small contribution of a $\mathrm{K}^{+}$conductance, which could have been overlooked in the preceding experiments. For this purpose, solutions containing only $\mathrm{K}^{+}$as a possible permeating ion (ExK and InK; $E_{\mathrm{K}}=-88 \mathrm{mV}$ ) were used. In 8 out of 12 cells investigated within the first $2 \mathrm{~d}$ in culture, no sign of a $\mathrm{K}^{+}$current was found. In the 4 remaining cells, outward currents of 90 $440 \mathrm{pA}$ were measured at holding potentials of $+60 \mathrm{mV}$. Figure 4 shows recordings from the cell with the largest $\mathrm{K}^{+}$current seen within the first $2 \mathrm{~d}$ in culture. When ExK was replaced by ExNa, in 6 out of the 7 cells tested, small inward currents ranging between -60 and $-180 \mathrm{pA}$ were recorded upon 5-HT application at negative holding potentials $(-60 \mathrm{mV})$, suggesting an additional $\mathrm{Na}^{+}$permeability. Changing to superfusion with ExCl solution, outward currents carried by $\mathrm{Cl}^{-}$influx were again revealed in all cells. These $\mathrm{Cl}^{-}$currents ranged between 800 and $3000 \mathrm{pA}$ at a membrane potential of $+60 \mathrm{mV}$, by far exceeding the amplitudes of the cation currents. For cells showing both $\mathrm{Na}^{+}$and $\mathrm{K}^{+}$currents (Fig. 4), the slope conductances for monovalent ions were estimated to $4 \pm 2 \mathrm{nS}$ (mean $\pm \mathrm{SD} ; n=6$ ). This is only half of the value of $9.6 \pm 1.4 \mathrm{nS}$ given by Drapeau et al. (1989).

In the following experiment, we tested whether the 5-HTinduced currents might have been altered as a result of the enzymatic treatment. Thus, the experiments were repeated on cells removed from the ganglia exclusively mechanically $1-4 \mathrm{~d}$ prior to the experiments. To test for possible $\mathrm{Cl}^{-}, \mathrm{K}^{+}$, and $\mathrm{Na}^{+}$con-

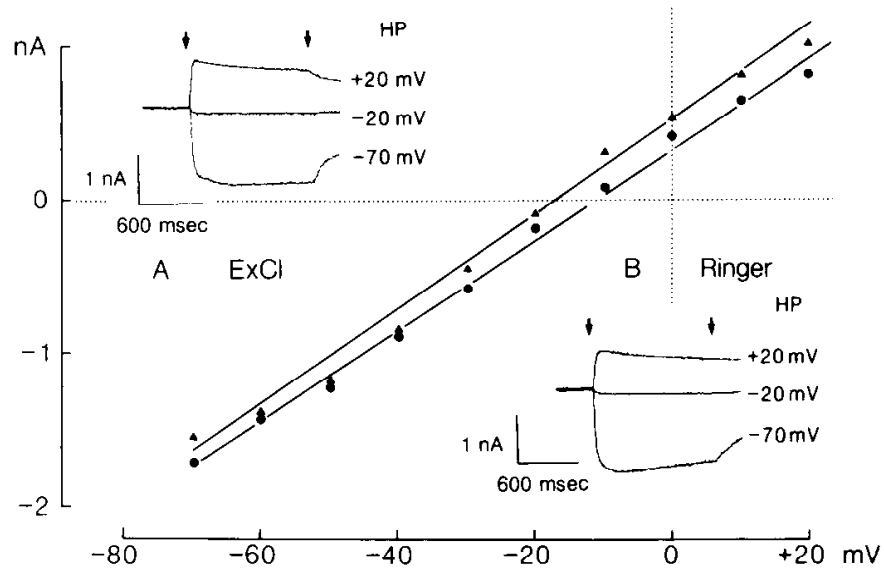

Figure 3. Reversal potential of 5-HT-induced currents in an adult Retzius cell. The cell was removed after collagenase treatment and maintained in culture for $2 \mathrm{~d}$. Internal solution, $\mathrm{InCl}\left(127 \mathrm{mM} \mathrm{Cl}^{-} ; \mathrm{Na}^{+}\right.$and $\mathrm{K}^{+}$replaced by NMDG). $A$, Current-voltage relation for responses to 5-HT application $(200 \mu \mathrm{M})$ in ExCl solution $\left(\Delta ; 156 \mathrm{mM} \mathrm{Cl}^{-} ; \mathrm{Na}^{+}\right.$and $\mathrm{K}^{+}$replaced by NMDG; $E_{\mathrm{Cl}}$ calculated to $-5 \mathrm{mV}$ ). Inset shows original current recordings at holding potentials as indicated $(H P)$. Arrows indicate duration of 5-HT administration. $B$, Current-voltage relation of currents recorded in Ringer's solution $\left(117 \mathrm{~mm} \mathrm{Cl}, 115 \mathrm{~mm} \mathrm{Na} \mathrm{Na}^{+}, 4\right.$ $\mathrm{mm} \mathrm{K} \mathrm{K}^{+} ; E_{\mathrm{Cl}},+2 \mathrm{mV}$ ). The inset shows some of the original current recordings at holding potentials as indicated. Lines were fit by linear regression.

ductances in the same cell, InK solution was used in the pipette, and 5-HT was administered successively in ExK, ExNa, and ExCl solutions. In all 8 cells tested, no sign of any $\mathrm{K}^{+}$conductance was found. Upon administration of ExNa solution, $\mathrm{Na}^{+}$ currents were found in 6 out of 7 neurons (at $-60 \mathrm{mV}$ holding potential, -50 to $-120 \mathrm{pA}$ after $1 \mathrm{~d}$ in culture, -180 to -300 pA after $4 \mathrm{~d}$ in culture). As expected for $\mathrm{Na}^{+}$currents, these inward currents increased with more negative membrane potentials. At high depolarizations in ExNa solution, $\mathrm{K}^{+}$outward currents possibly overlooked in ExK solution should be unmasked because of the even lower $\mathrm{K}^{+}$concentration in ExNa compared to ExK. In agreement with the results obtained with ExK solution, in 7 out of 8 cells, however, no indication of a $\mathrm{K}^{+}$current was seen. When ExNa was replaced by ExCl solution, outward currents were recorded in all cells, as expected, reaching $1100-3600 \mathrm{pA}$ at a holding potential of $+60 \mathrm{mV}$. These results gave no indication of a loss of 5-HT-activated cation channels caused by the collagenase treatment.

To find out whether cation conductances become more dominant with time in culture, experiments were repeated on Retzius cells cultured for 6-10 d. While $\mathrm{Cl}^{-}$currents measured in $\mathrm{ExCl}$ had approximately the same amplitude at $+60 \mathrm{mV}(2500 \pm$ $1300 \mathrm{pA}$ ) as in cells maintained for a shorter time in culture, $\mathrm{Na}^{+}$currents of significantly larger amplitude were now found in several cells (up to $900 \mathrm{pA}$ at a holding potential of -60 $\mathrm{mV}$ ).

In summary, in all 32 adult cells examined between $1-10 \mathrm{~d}$ in culture, 5-HT application induced $\mathrm{Cl}^{-}$currents. From the 21 cells examined between 1 and $6 \mathrm{~d}$ for a contribution of $\mathrm{K}^{+}$or $\mathrm{Na}^{+}$currents in isolation, $\mathrm{Na}^{+}$currents were undetectable (below $10 \mathrm{pA}$ ) in 2 cells, and no indication of $\mathrm{K}^{+}$currents was seen in 14 cells. Because $\mathrm{Na}^{+}$currents of up to $800 \mathrm{pA}$ were seen in the absence of $\mathrm{K}^{+}$currents, and because $\mathrm{K}^{+}$currents did not correlate in any way in amplitude with $\mathrm{Na}^{+}$currents of the same cells (Fig. 5), we suggest that both currents possibly flow through 
Figure 4. Separation of 5-HT-induced $\mathrm{Cl}^{-}, \mathrm{K}^{+}$, and $\mathrm{Na}^{+}$currents of an adult Retzius cell. The cell was removed after collagenase treatment and maintained in culture for $2 \mathrm{~d}$. Internal solution, $\mathrm{InK}\left(133 \mathrm{mM} \mathrm{K}^{+} ; \mathrm{Cl}^{-}\right.$replaced by gluconate). $A$, Currents induced by switching the perfusion from an extracellular solution containing $4 \mathrm{~mm} \mathrm{~K}^{+}$ and no $\mathrm{Na}^{+}$or $\mathrm{Cl}^{-}(\mathrm{ExK})$ to same solution containing $200 \mu \mathrm{M} 5-\mathrm{HT}$ (for time indicated by arrows) at different holding potentials $(H P)$. $B$ and $C$, Same $5-\mathrm{HT}$ concentration as in $A$ applied in ExNa solution $\left(B ; 80 \mathrm{mM} \mathrm{Na}^{+} ;\right.$no $\mathrm{K}^{+}$or $\left.\mathrm{Cl}^{-}\right)$ and in ExCl solution $\left(C ; 156 \mathrm{~mm} \mathrm{Cl}^{-}\right.$; no $\mathrm{Na}^{+}$or $\left.\mathrm{K}^{+}\right) . D$, Peak currents versus holding potential for the 5-HT responses in the 3 different solutions. Curves were fit by eye.

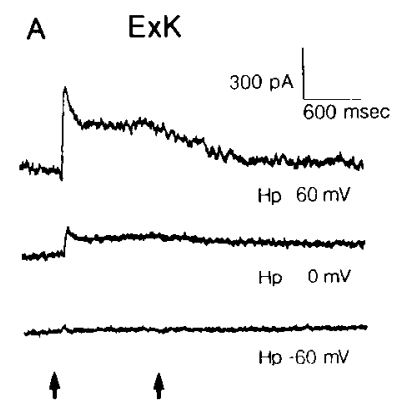

B ExNa
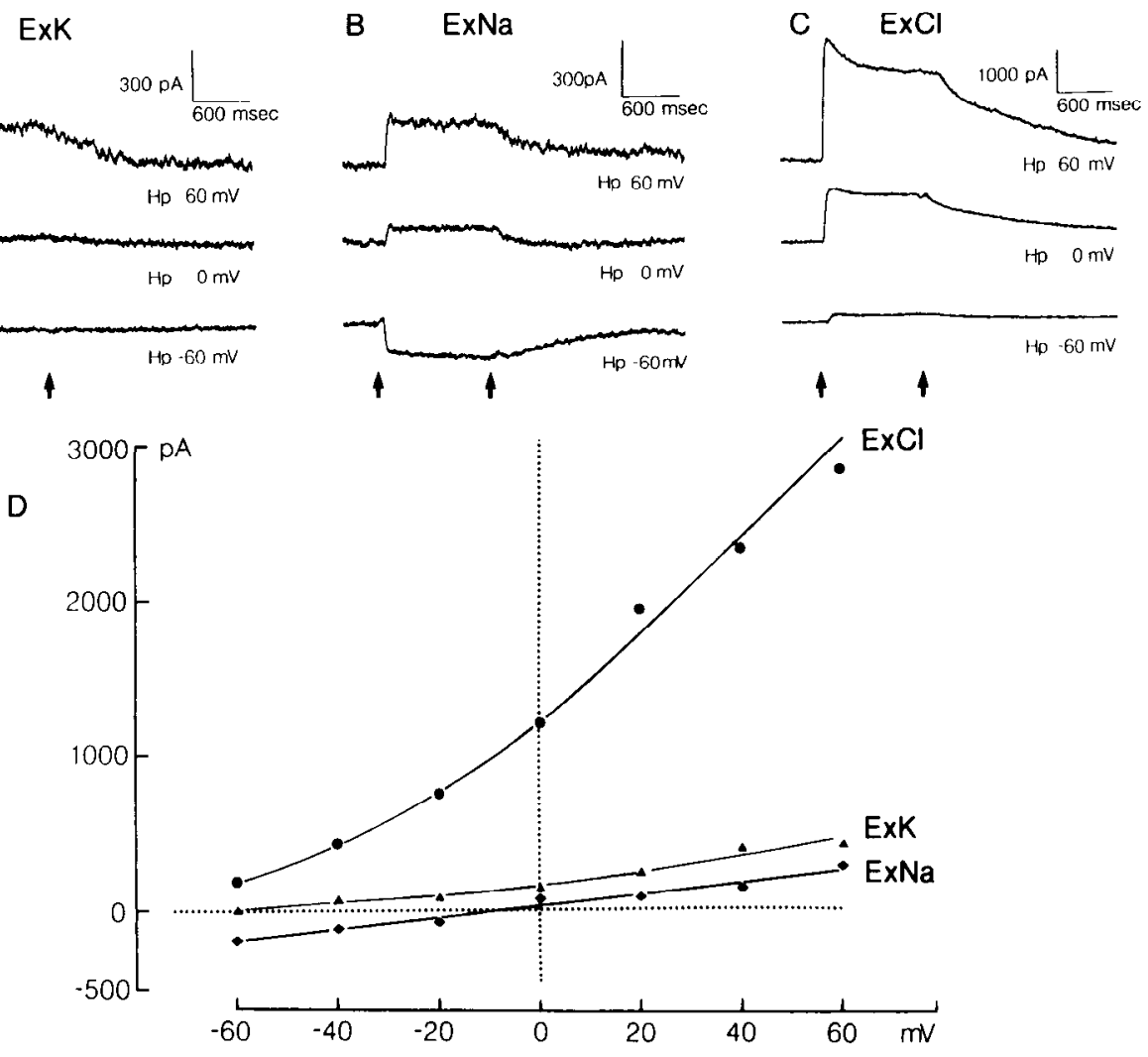

separate ion channels. Furthermore, our data indicate that the amplitude of these cation currents increases in response to prolonged culture or denervation. Because embryonic cells were investigated within the first $24 \mathrm{hr}$ in culture, no more experiments were carried out to corroborate this finding.

Embryonic Retzius cells. The following experiments were conducted to find out when 5-HT responses arise during embryogenesis and whether they differ from those of adult Retzius cells. Because embryonic Retzius cells could not unambiguously be identified by morphological criteria, they were stained prior to dissociation by uptake of the autofluorescent 5-HT analog 5,7DHT (see Materials and Methods). Embryonic Retzius cells incubated for 4-12 hr in a 5,7-DHT solution $(300 \mu \mathrm{M})$ could be identified after dissociation by their faint violet-blue fluorescence (Fig. $6 C, D$ ). The lateral cells, which are also stained, are assumed to be identical with the antero- and posterolateral pairs of serotoninergic cells (Marsden and Kerkut, 1969; Rude, 1969; Lent et al., 1979). Although both cell types increased in soma size after E7, at all stages, Retzius cells were about twice as large as the lateral cells. The ratios of the diameters were $1.8 \pm 0.3$ $($ mean $+\mathrm{SD}$ ) in 8 investigated ganglia between F.9 and F.1 2 (Fig. $6 B)$ and $2.4 \pm 0.6(n=4)$ for cells of adult ganglia. Recording from the largest of the stained cells in the dish thus ensured that Retzius cells were selected. These had normal morphological appearance (including neurite outgrowth visible after ca. $12 \mathrm{hr}$ in culture) and resting potentials of -50 to $-60 \mathrm{mV}$ (InP/ Ringer's) and were able to fire overshooting action potentials during the $2 \mathrm{~d}$ in culture within which investigations were performed (Fig. $6 E$ ). These findings demonstrate that, under our conditions, the cytotoxic effects described by Glover and Kramer (1982) were absent (see also Lent and Dickenson, 1984). Likewise, catecholaminergic neurons from embryonic rat mes- encephalon have been described to maintain their excitability, if stained in solutions of up to $50 \mu \mathrm{M}$ 5,7-DHT for 30-60 min (Silva et al., 1988). The actual source of neurotoxicity of this drug is thought to result from its enzymatic or oxidative degradation products (Creveling et al., 1975; Rotman et al., 1976; for reviews, see Jacoby and Lytle, 1978), which seem to be ineffective in our preparation.

The first responses to 5-HT application became measurable in embryonic neurons that were incubated at E10 and finally recorded from at E11. (If not stated otherwise, the indicated age refers to the date of isolation of the ganglia.) They consisted of small transients, the maximal amplitudes of which amounted to $20 \mathrm{pA}$ (at $+40 \mathrm{mV}$ holding potential) in $\mathrm{ExCl}$ and InK solutions (Fig. 7). When superfused with ExNa and ExK, no responses were seen, suggesting that the $\mathrm{Cl}^{-}$current is the first current to become measurable. All Retzius cells older than E13 at the day of preparation showed clear 5-HT-induced responses that were mediated by $\mathrm{Cl}^{-}$currents $(n=42)$ and increased in size with embryonic age. To test whether the augmentation of the $\mathrm{Cl}^{-}$current merely reflected the concomitant enlargement of the surface area of the cell, or whether a true increase in channel density occurred, the average amplitude of $\mathrm{Cl}^{-}$currents measured at $+40 \mathrm{mV}$ in $\mathrm{InK} / \mathrm{ExCl}$ solution was divided by the estimated surface area of the cells. Experiments were performed on cells that showed no significant neurite outgrowth. Hence, the cell surface could be estimated under the assumption of a spherical geometry after determining the cell diameters with a measuring ocular. No attempts were made to determine the membrane surface by additional capacitance measurements. While geometrical estimates neglect the effect of possible membrane infoldings. capacitance measurements could suffer from errors of compensation of electrode capacitance and leakage 


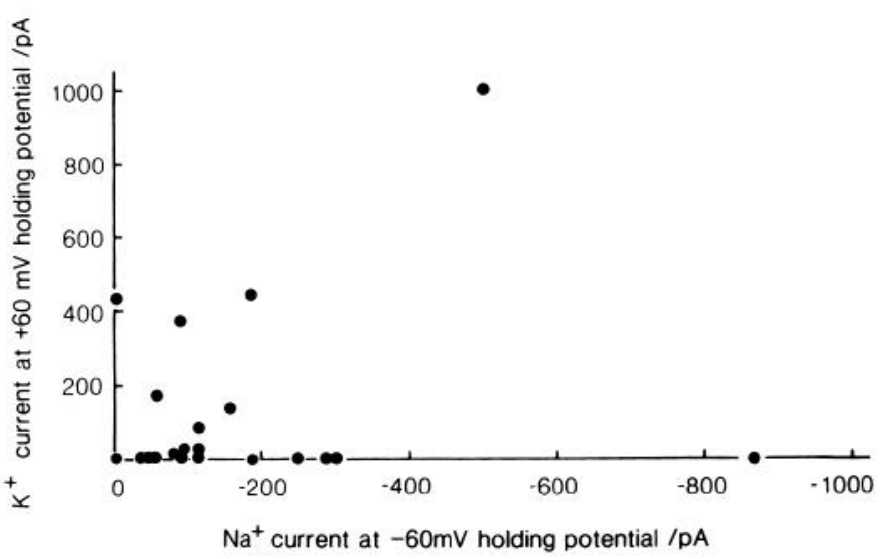

Figure 5. Lack of correlation between 5-HT-induced $\mathrm{Na}^{+}$and $\mathrm{K}^{+}$currents in adult Retzius cells. The amplitude of 5-HT-induced currents in ExK solution (measured at $+60 \mathrm{mV}$ holding potential, peak $\mathrm{K}^{+}$ current) was plotted against the peak $\mathrm{Na}^{+}$current recorded in the same cell (in ExNa solution at a holding potential of $-60 \mathrm{mV}$ ). If $\mathrm{Na}^{+}$and $\mathrm{K}^{+}$ions use the same channel, the dots should give a line. Linear regression analysis confirmed the poor correlation between both currents $(r=0.3 ; p=0.38)$.

current. Furthermore, it has not been clarified whether the relevant ion channels are present on the infoldings in the same density as on the outer surface of the cell. Finally, Streit and Lux (1987) observed parallel changes between increases in capacitance and growth of soma size in PC12 cells. Keeping in mind that the determination of current densities on the basis of geometrical determinations of soma size might lead to overestimated absolute values, our data suggest a continuous increase in the current density between E10, E17, and adulthood (Fig. 8), suggesting a relatively larger synthesis of transmitteractivated channels during embryogenesis than of cell surface.

Starting at E12, a persistent current component was seen in addition to the transient one. These 2 components were generally observed (Fig. 9), regardless of the solutions employed, in cells of all ages, including adult cells, if the perfusion pipette (tip diameter, ca. $200 \mu \mathrm{m}$ ) was carefully adjusted to allow a sufficiently fast exchange of the solution surrounding the entire cell. The ratio of peak and plateau currents at fixed holding potentials differed from cell to cell and could not be related to the age of the embryos. Also, for the same cell, this ratio differed with changing holding potentials. These findings could indicate that 2 different $\mathrm{Cl}^{-}$channels are activated by $5-\mathrm{HT}$ application.

From the transient peak, the currents decayed with time constants of $67 \pm 17$ msec (mean $\pm S D ; 13$ cells) to a plateau level, which was maintained during continuing perfusion. For adult cells, slightly slower time constants were found: $92 \pm 25 \mathrm{msec}$ ( 8 cells). A slowing of the decay time constant could be a result of maturation, but could as well be caused by less synchronized activation of the channels on the larger adult cells. Single-channel analysis will have to be performed to clarify this point. Most interestingly, the time constants of inactivation were close to the fast decay time constant of synaptic currents $(70 \mathrm{msec}$; Drapeau and Sanchez-Armass, 1988). Both decay time constants were also independent from holding potential.

The recovery after washing with extracellular control solutions was much slower than the onset of the response (Fig. 9). The slow recovery could be due to persisting binding of 5-HT to the membrane or delays inherent in the responses of a secondmessenger cascade (Sanchez-Armass et al., in press). All external
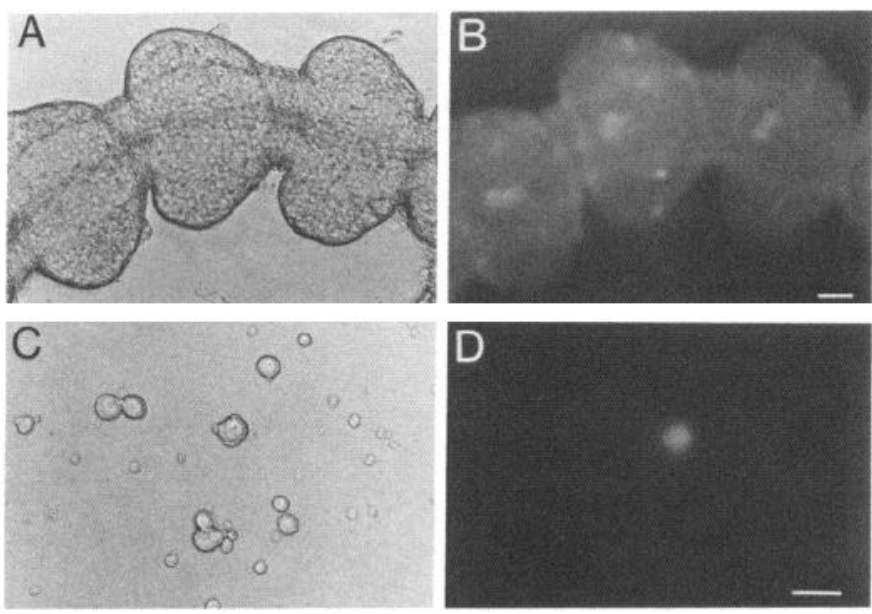

$\mathrm{E}$

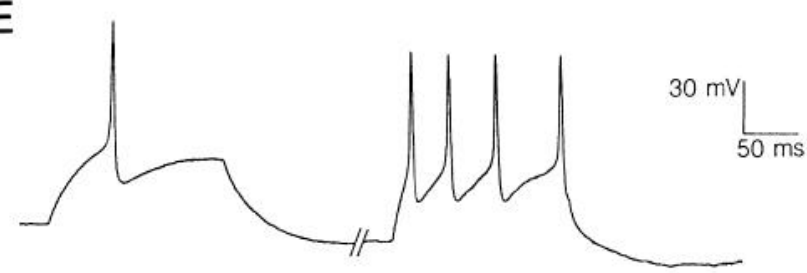

Figure 6. Vital staining of embryonic Retzius cells. A, Phase-contrast microphotograph of 3 succeeding segmental ganglia isolated from an embryo at E12. B, Same ganglia after incubation in 5,7-DHT solution and viewed with fluorescence filters and mercury vapor lamp (filter combination: BP 365, FT 390, LP 397). Note the paired embryonic Retzius cells in the center of each ganglion. The significantly smaller lateral serotonin-containing cells also accumulated the dye. $C$, Phasecontrast micrograph of embryonic cells, dissociated from E16 ganglia. $D$, Same cells as in $C$ seen through the fluorescence filters. In the center, only one of the larger cells was stained and thus identified as an embryonic Retzius cell. Scale bars, $40 \mu \mathrm{m}$. E, Depolarizing currents of 40 and $100 \mathrm{pA}$, respectively, revealed the ability of such identified cells to fire (repetitive) action potentials.
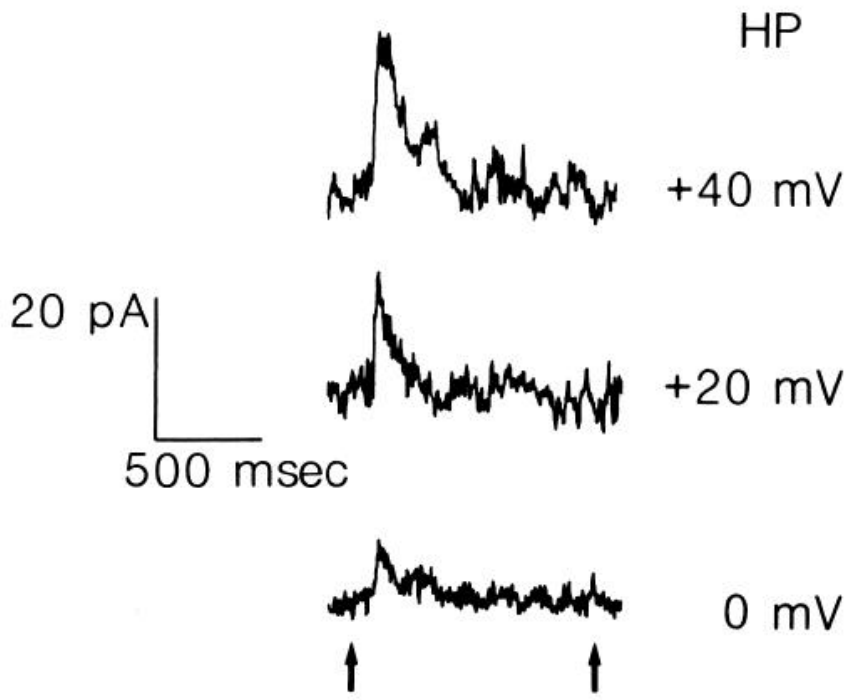

Figure 7. Responses to 5-HT of an identified embryonic Retzius cell, isolated at E10, recorded at E11. Pipette solution, InK $\left(133 \mathrm{~mm} \mathrm{~K}^{+}\right.$as only permeant ion). 5-HT was applied in $\mathrm{ExCl}$ solution $\left(\mathrm{Cl}^{-}\right.$as only permeant ion) for time indicated by arrows at different holding potentials $(H P)$. 


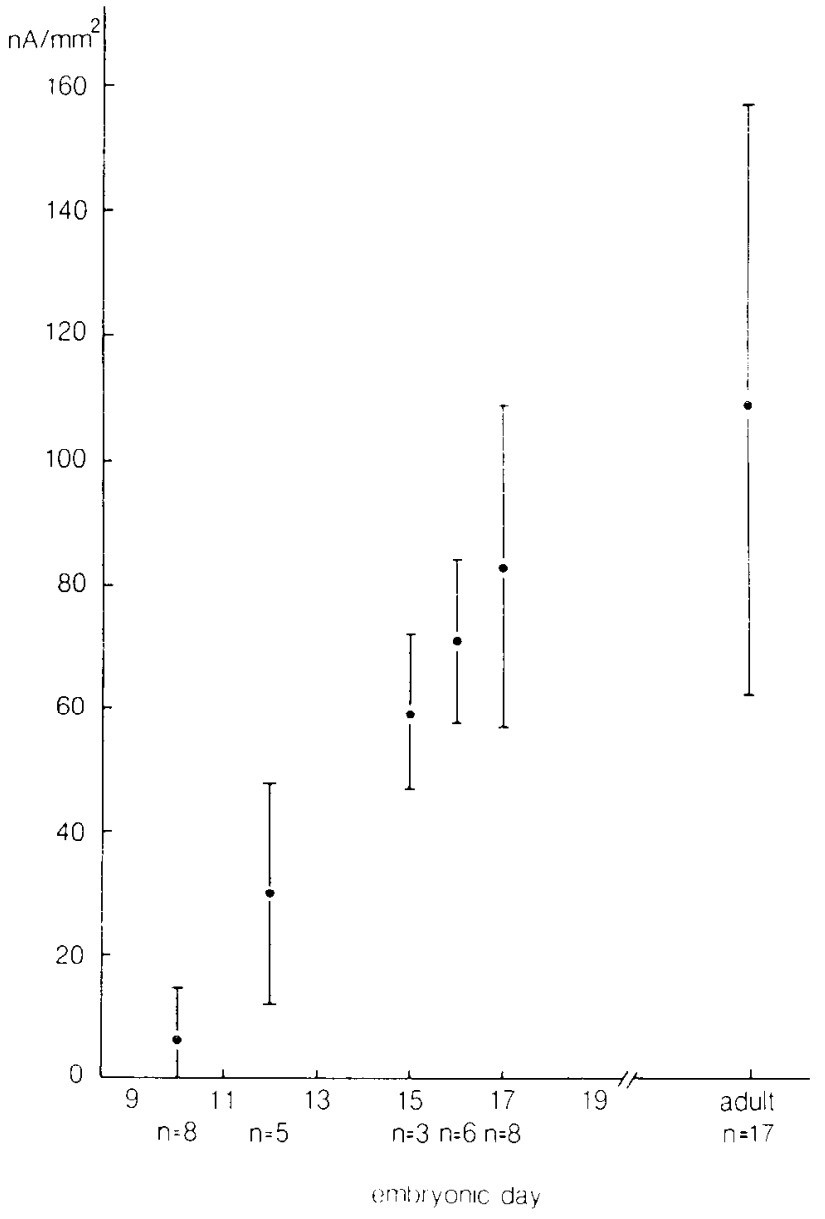

Figure 8. Current density (peak amplitude of 5-HT-induced $\mathrm{Cl}^{-}$current at a holding potential of $+40 \mathrm{mV}$ divided by estimated cell surface area) versus age of embryos at time of preparation. Solutions, InK/ExCl. Vertical bars represent SD. Parametric ANOVA revealed a statistically significant difference between the groups $[(5,41) F$ ratio $=26.3 ; p<$ 0.0001 ; see, e.g., Zar, 1974], confirming the visually appearent increase in current density with age.

solutions contained $1.8 \mathrm{mM} \mathrm{Ca}^{2+}$ to stabilize the seals. No contribution of $\mathrm{Ca}^{2+}$ currents could be inferred from the reversal potentials of the $\mathrm{Cl}^{-}$-mediated 5-HT response. However, several transmitter-activated currents depend on the extracellular $\mathrm{Ca}^{2+}$ concentration. For instance, in glutamate-activated channels of crayfish muscle, a rise in extracellular $\mathrm{Ca}^{2+}$ between 1 and 10 mм increases the open time of the channels and the rate of openings (Hatt et al., 1988). Therefore, a possible influence of the external $\mathrm{Ca}^{2+}$ ions on the $\mathrm{Cl}^{-}$currents in our preparation was additionally tested. Cells were investigated in $\mathrm{InCl} / \mathrm{ExCl}$ solutions, where the $\mathrm{Ca}^{2+}$ concentration in $\mathrm{ExCl}$ solution contained either 1.8 or $10 \mathrm{mM} \mathrm{Ca}^{2+}$. The increase in the $\mathrm{Ca}^{2+}$ concentration did not result in a consistent change of the response to 5-HT (not shown).

Twenty-five embryonic Retzius cells were tested for 5-HTactivated $\mathrm{Na}^{+}$and $\mathrm{K}^{+}$currents in addition to $\mathrm{Cl}^{-}$currents using the same experimental design as for adult cells. $\mathrm{No}^{+}$or $\mathrm{Na}^{+}$ currents were measurable in Retzius cells from embryos younger than E17. At E17, 1 out of 8 cells showed a 5-HT-induced $\mathrm{K}^{+}$ current in addition to a $\mathrm{Cl}^{-}$current.

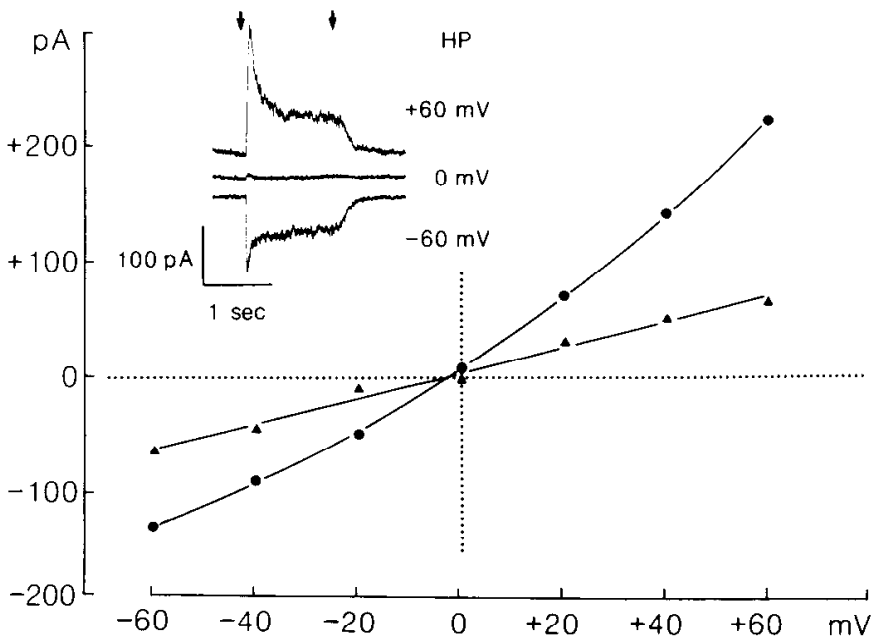

Figure 9. Transient and persistent component of 5-HT-induced ion currents of an embryonic Retzius cell isolated at El6. Internal solution, InCl $\left(127 \mathrm{mM} \mathrm{Cl}^{-}\right.$as only permeant ion). External solution, $\mathrm{ExCl}$ (156 $\mathrm{mM} \mathrm{Cl}{ }^{-}$as only permeant ion). Current-voltage relationship for peak $(\boldsymbol{)})$ and plateau $(\boldsymbol{\Delta})$ current is shown. Inset shows original current traces at indicated holding potentials $(H P)$. Duration of transmitter application is indicated by arrow's.

\section{Discussion}

Our experiments show that the first 5-HT-activated currents in developing Retzius cells are carried by $\mathrm{Cl}^{-}$ions, which also dominate the 5-HT response of adult cells (Walker and Smith, 1973; Cemerikić et al., 1985; Drapeau et al., 1989). The first responses to 5-HT were recorded at E10. At this time, all larger cells in the ganglia, including the Retzius cells, have already expressed voltage-dependent $\mathrm{Na}^{+}$and $\mathrm{Ca}^{2+}$ channels (Gottmann et al., 1989; Schirrmacher and Deitmer, 1991). At E7, Retzius cells start to grow neurites and metabolize monoamines, as shown with anti-5-HT antibodies (Glover and Mason, 1986) and glyoxylic acid condensation after dopamine uptake (Dietzel and Gottmann, 1988).

The finding that transmitter-activated conductances become measurable shortly after voltage-dependent conductances agrees well with investigations in Rohon-Beard neurons of Xenopus. Bixby and Spitzer (1982) found that electrical excitability develops and the action potential changes its shape from a $\mathrm{Ca}^{2+}$ to an $\mathrm{Na}^{+}$-dominated spike prior to the expression of a GABAactivated conductance. Transmitter-activated channels were also measured several days after voltage-activated channels appeared in tectal neurons of embryonic rats (Perouansky and Grantyn, 1988). In contrast, in DUM neurons of the grasshopper, GABA- and ACh-activated membrane potential changes have been observed to appear before any sign of action potential activity is evident (Goodman and Spitzer, 1979, 1980). In the developing neuromuscular junction of Xenopus as well as in tunicate muscle, ACh sensitivity appeared approximately at the same time as the action potential (Blackshaw and Warner, 1976; Ohmori and Sasaki, 1977).

Our observation that transmitter-activated channels follow the voltage-gated channels does not, however, necessarily imply that transmitter-gated channels are expressed later than voltagegated channels. It has to be kept in mind that, in general, voltageactivated currents are larger (40-nA Ca ${ }^{2+}$ current, $100-\mathrm{nA} \mathrm{Na}^{+}$ current) in Retzius cells, compared to transmitter-activated cur- 
rents, where amplitudes of more than $3 \mathrm{nA}$ have never been measured (see also Drapeau and Sanchez-Armass, 1988). That the appearance of transmitter-activated currents is not, however, merely a result of the increasing size of the membrane, and concomitantly, the increasing number of channels, is evidenced from Figure 8, where the increase in current density was estimated with embryonic age: The amplitudes of the measured currents increased more with age than did the surface area of the cells, suggesting a true increase in the channel densities. Moreover, the increase of current density with maturation as shown in Figure 8 might suggest the beginning of the expression of 5-HT-sensitive channels close to E9, which is later than the appearance of voltage-gated $\mathrm{Na}^{+}$channels at E7. Small densities of 5-HT-induced currents of Retzius cells in intact ganglia between E10 and E1 2 are also suggested by experiments of Schirrmacher and Deitmer (1989), who failed to detect transmitterinduced membrane potential changes at this age.

In accordance with other investigations, our results indicate that transmitter-gated ion channels appear in close temporal relation to the expression of other phenotypes of differentiated neurons, such as neurite outgrowth and voltage-gated $\mathrm{Na}^{+}$and $\mathrm{Ca}^{2+}$ channels.

During the following days of embryo genesis, the current densities of the 5-HT-gated $\mathrm{Cl}^{-}$current gradually increased (see also Bixby and Spitzer, 1982). In Hirudo, to our knowledge, no information about the time of onset of chemical synaptic transmission is available. However, recordings in a different species of leech, Haementaria ghilianii, indicate a first occurrence of spontaneous synaptic potentials in P-cells and motoneurons several days after action potentials can be recorded. At this time, neurites have already started to grow for about a week, a considerable morphological maturation has occurred, and the formation of the peripheral reccptive ficlds is well under way (Kramer and Kuwada, 1983; Kuwada and Kramer, 1983; Kuwada, 1984). Assuming an analogous development of neurite outgrowth and germinal plate in Haementaria and Hirudo, the stage where first action potentials were recorded in P-cells [stage 10(0/ 5)] corresponds to about Ell in Hirudo, while first synaptic potentials were seen at about E14 [stage 10(2/5)]. In L-motoneurons, action potentials were recorded at stage $10(1 / 5)$, corresponding to $E 12$, and first synaptic potentials evoked by stimulation of the contralateral P-cells were observed at stage 11(0/ 20 ), corresponding to $\mathrm{E} 18$. In the present study, first responses to 5-HT were measured in Retzius cells of Hirudo at E10. By this time, neurites have grown for about $2 \mathrm{~d}$ and will reach their peripheral targets within the next $2 \mathrm{~d}$ (Glover and Mason, 1986; Dietzel and Gottmann, 1988). The time of increase in functional 5-HT receptors hence coincides with the time of extension of neurites and occurs prior to the establishment of final connections.

In adult cells, a more detailed separation of the ion currents underlying the cation conductance leads us to suggest that separate $\mathrm{Na}^{+}$and $\mathrm{K}^{+}$channels may compose the 5-HT-induced monovalent conductance in Retzius cells: Several cells were found that showed an $\mathrm{Na}^{+}$current, but no signs of any $\mathrm{K}^{+}$ current. Furthermore, the amplitudes of the $\mathrm{Na}^{+}$and $\mathrm{K}^{+}$currents did not correlate in any systematic manner (Fig. 5). In cells where the composite cation conductance could be determined, we obtained conductances half as large as those reported by Drapeau et al. (1989). This discrepancy can be explained by assuming that the number of cation channels (especially of $\mathrm{Na}^{+}$ channels) increases with time in culture (possibly as the result of loss of contact). While we recorded larger $\mathrm{Na}^{+}$currents in some cells cultured for more than $5 \mathrm{~d}$, Drapeau et al. (1989) conducted most of their experiments on cells cultured for 7-10 d. In any case, the lack of cation currents in freshly cultured cells was not a result of the collagenase treatment.

While cation currents were elicited by direct $5-\mathrm{HT}$ application onto the soma (see also Drapeau et al., 1989), synaptic responses, as far as analyzed, were mediated by $\mathrm{Cl}^{-}$currents in cultured Retzius-Retzius cell pairs (Liu and Nicholls, 1989). Although it is unclear whether cation channels could be involved in some yet unknown synaptic responses of the Retzius cell, present evidence suggests an extrasynaptic role. Extrasynaptic receptors could function to modulate the firing behavior of the cell in response to changes in the 5-HT level in the blood. One could imagine that changes in the expression of relative quantities of $\mathrm{Cl}^{-}$channels and cation channels could adapt the cell to changing conditions, possibly also during maturation. In embryonic neurons, no sign of cation currents was seen in cells younger than $\mathrm{E} 17$, and only 1 cell with a small indication of a $\mathrm{K}^{+}$current was recorded from at this age. By this time, $\mathrm{Cl}$ currents reach amplitudes of $200 \mathrm{pA}$, such that 10-times-smaller currents can be seen. This suggests that, during embryogenesis, the same ratio between $\mathrm{Cl}^{-}$and cation channels as in adult cells may occur.

At the neuromuscular junction (for review, see Brehm and Henderson, 1988) as well as at Retzius-P-cell synapses (Drapeau et al., 1989), contact to the presynaptic neuron seems to downregulate extrasynaptic channels. While these investigations suggest a regulatory role of the presynaptic neuron on the expression of transmitter-activated channels, such influences are obviously restricted to a narrow choice of possible receptor-channel complexes or channel subunit compositions. This limitation of developmental changes of transmitter responses is also suggested by studies that demonstrated no changes in ion selectivities of the transmitter response during embryogenesis: the GABA-activated increase of the $\mathrm{Na}^{+} / \mathrm{K}^{+}$conductance in Xenopus neurons (Bixby and Spitzer, 1982), the GABA-activated $\mathrm{Cl}^{-}$conductance as well as the $\mathrm{ACh}$-activated $\mathrm{Na}^{+}$conductance in grasshopper DUM neurons (Goodman and Spitzer, 1979, 1980), the AChactivated $\mathrm{Na}^{+} / \mathrm{K}^{+}$conductance in rat and chick myotubes (Ritchie and Fambrough, 1975), and the ACh sensitivity in Xenopus muscle (Blackshaw and Warner, 1976). No obvious differences in transmitter responses from embryonic and adult Retzius cells of the leech were also found in this study. Whether this lack of change could be due to a constancy of the surrounding factors that determine the expression of 5-HT-activated channels or to an independence of channel expression on environmental factors will have to be answered by studies on identified embryonic cells grown for longer periods in isolation.

As with many transmitter-activated currents, we also observed desensitizing responses (see, e.g., Katz and Thesleff, 1957; Epstein and Grundfest, 1970; Adams, 1975; Adams and Brown, 1975; Bixby and Spitzer, 1982; Dudel et al., 1990). Although desensitization of P-cell responses to 5-HT application has been previously noticed (Henderson, 1983), the fast desensitizing transient of the 5-HT-induced response has not been reported in other studies of leech Retzius cells and has been revealed by the fast application system in combination with the high concentration of 5-HT used.

All but the very youngest cells showed a transient as well as a persistent $\mathrm{Cl}^{-}$current in response to 5 - $\mathrm{HT}$ application. Because no obvious and consistent ratio was found between both com- 
ponents, this could indicate that more than 1 subtype of 5-IITgated $\mathrm{Cl}^{-}$channel exists in these neurons. Variations in the rate of change of the perfusion solution could, in principle, also explain different ratios of transient versus persistent components. They could not, however, explain why the current-voltage relation of the peak current often showed an outward rectification, which the persistent component did not display (Fig. 9). Evidence that similar transient and plateau components of quisqualate-induced currents in rat hippocampal neurons could arise from different channel populations has been presented by Tang et al. (1989). Single-channel recordings and investigations with specific antagonists will have to be performed to find out whether several subtypes of 5-HT-activated ion channels are expressed in our preparation as well, or whether the observed kinetics can be explained on the basis of desensitization only. Interestingly, in this preparation, like in others (Tang et al., 1989; Dudel et al., 1990; Lester et al., 1990), the time constant of the desensitization was close to that of the decay of the postsynaptic current.

No obvious changes in inactivation kinetics, indicating changes in gating properties, as described for $\mathrm{ACh}$-sensitive ion channels and synaptic currents during development of neuromuscular end plates (for review, see, e.g., Sakmann and Brenner, 1978; Brehm and Henderson, 1988), were observed. Whether the small increase in the time constant of desensitization seen in adult versus embryonic cells reflects true changes in channel gating has to be revealed by single-channel recordings.

\section{References}

Adams PR (1975) A study of desensitization using voltage clamp. Pfluegers Arch 360:135-144.

Adams PR, Brown DA (1975) Actions of $\gamma$-aminobutyric acid on sympathetic ganglion cells. J Physiol (I ond) 250:85-120.

Bixby JL, Spitzer NC (1982) The appearance and development of chemosensitivity in Rohon-Beard neurones of the Xenopus spinal cord. J Physiol (Lond) 330:513-536.

Blackshaw S, Warner A (1976) Onset of acetylcholine sensitivity and endplate activity in developing myotome muscles of Xenopus. Nature 262:217-218.

Blackshaw SE, Thompson SWN (1988) Hyperpolarizing responses to stretch in sensory neurones innervating leech body wall muscle. $J$ Physiol (Lond) 396:121-137.

Brehm P, Henderson LP (1988) Regulation of acetylcholine receptor channel function during development of skeletal muscle. Dev Biol 129:1-11.

Carbone E, Lux HD (1987) Kinetics and selectivity of a low-voltageactivated calcium current in chick and rat sensory neurones. I Physiol (Lond) 386:547-570.

Cemerikić D, Nedeljkov V, Beleslin B (1985) Effect of 5-HT on cellular chloride activity in Retzius nerve cells of the leech. Periodicum Biologorum 87:211-213.

Creveling CR, Lundstrom J, McNeal ET, Tice L, Daly JW (1975) Dihydroxytryptamines: effects on noradrenergic function in mouse heart in vivo. Mol Pharmacol 11:211-222.

Davies NW, Lux HD, Morad M (1988) Site and mechanism of activation of proton-induced sodium current in chick dorsal root ganglion neurones. J Physiol (Lond) 400:159-187.

Dietzel ID, Gottmann K (1988) Development of dopamine-containing neurons and dopamine uptake in embryos of Hirudo medicinalis. Dev Biol 128:277-283.

Dietzel ID, Drapeau P, Nicholls JG (1986) Voltage dependence of 5 hydroxytryptamine release at a synapse between identified leech neurones in culture. J Physiol (Lond) 372:191-205.

Drapeau P, Sanchez-Armass S (1988) Selection of postsynaptic serotonin receptors during reinnervation of an identified leech neuron in culture. $J$ Neurosci 8:4718-4727.

Drapeau P, Melinyshyn E, Sanchez-Armass S (1989) Contact-mediated loss of the nonsynaptic response to transmitter during reinner- vation of an identificd lecch neuron in culturc. J Ncurosci 9:25022508.

Dudel J, Franke C, Hatt H (1990) Rapid activation, desensitization, and resensitization of synaptic channels of crayfish muscle after glutamate pulses. Biophys J 57:533-545.

Epstein R, Grundfest H (1970) Desensitization of gamma aminobutyric acid (GABA) receptors in muscle fibers of the crab Cancer borealis. J Gen Physiol 56:33-45.

Erwin DN, Thies RE (1975) Effect of neuraminidase + ethylenediaminetetraacetic acid (EDTA) upon the serotonin receptors of Retzius' cells in the leech. Fed Proc 34:359.

Fernández J, Stent GS (1982) Embryonic development of the hirudinid leech Hirudo medicinalis: structure, development and segmentation of the germinal plate. J Embryol Exp Morphol 72:71-96.

Fuchs PA, Nicholls JG, Rcady DF (1981) Membranc propertics and selective connexions of identified leech neurones in culture. J Physiol (Lond) 316:203-223.

Fuchs PA, Henderson LP, Nicholls JG (1982) Chemical transmission between individual Retzius and sensory neurones of the leech in culture. J Physiol (Lond) 323:195-210.

Glover JC, Kramer AP (1982) Serotonin analog selectively ablates identified neurons in the leech embryo. Science 216:317-319.

Glover JC, Mason A (1986) Morphogenesis of an identified leech neuron: segmental specification of axonal outgrowth. Dev Biol 115: 256-260.

Goodman CS, Spitzer NC. (1979) Embryonic development of identified neurones: differentiation from neuroblast to neurone. Nature 280:208-214.

Goodman CS, Spitzer NC (1980) Embryonic development of neurotransmitter receptors in grasshoppers. In: Receptors for neurotransmitters, hormones and pheromones in insects (Sattelle DB, Hall LM, Hildebrand JG, eds), pp 195-207. Amsterdam: Elsevier.

Gottmann K, Dietzel ID, Lux HD (1989) Proton-induced chloride current and voltage-activated $\mathrm{Na}^{+}$and $\mathrm{Ca}^{2+}$ currents in embryonic neurons from the medicinal leech (Hirudo medicinalis). Neurosci Lett 96:173-178.

Hatt H, Franke C, Dudel J (1988) Calcium dependent gating of the L-glutamate activated, excitatory synaptic channel on crayfish muscle. Pfiuegers Arch 411:17-26.

Henderson LP (1983) The role of 5-hydroxytryptamine as a transmitter between identified leech neurones in culture. J Physiol (Lond) 339:309-324.

Henderson LP, Kuffler DP, Nicholls J, Zhang R-J (1983) Structural and functional analysis of synaptic transmission between identified leech neurones in culture. J Physiol (Lond) 340:347-358.

Jacoby JH, Lytle LD (1978) Serotonin neurotoxins, Vol 305. New York: Annals of the New York Academy of Sciences.

Katz B, Thesleff S (1957) A study of the "desensitization" produced by acetylcholine at the motor end-plate. J Physiol (Lond) 138:63-80.

Kramer AP, Kuwada JY (1983) Formation of the receptive fields of leech mechanosensory neurons during embryonic development. J Neurosci 3:2474-2486.

Kuffler DP, Nicholls J, Drapeau P (1987) Transmitter localization and vesicle turnover at a serotoninergic synapse between identified leech neurons in culture. J Comp Neurol 256:516-526.

Kuwada JY (1984) Normal and abnormal development of an identified leech motor neuron. J Embryol Exp Morphol 79:125-137.

Kuwada JY, Kramer AP (1983) Embryonic development of the leech nervous system: primary axon outgrowth of identified neurons. $J$ Neurosci 3:2098-2111.

Lent CM, Ono J, Keyser KT, Karten HJ (1979) Identification of serotonin within vital-stained neurons from leech ganglia. J Neurochem 32:1559-1563.

Lent, CM, Dickenson MH (1984) Retzius cells retain functional membrane properties following "ablation" by the neurotoxin 5, 7-DHT. Brain Res 300:167-171.

Lester RAJ, Clements JD, Westbrook GL, Jahr CE (1990) Channel kinetics determine the time course of NMDA receptor-mediated synaptic currents. Nature 346:565-567.

Leuckart, R (1886) Die Parasiten des Menschen und die von ihnen herrührenden Krankheiten, ed 2. Leipzig: Winter'sche.

Lessmann V, Gottmann K, Dietzel ID (1990) Development of a serotonin-induced $\mathrm{Cl}^{-}$conductance in identified embryonic Retzius cells from the medicinal leech. Pfluegers Arch [Suppl] 415:R23.

Liu Y, Nicholls J (1989) Steps in the development of chemical and 
electrical synapses by pairs of identified leech neurons in culture. Proc R Soc Lond [Biol] 236:253-268.

Marsden CA, Kerkut GA (1969) Fluorescent microscopy of the 5-HTand catecholamine-containing cells in the central nervous system of the leech Hirudo medicinalis. Comp Biochem Physiol 31:851-862.

Medina IR, Bregestovski PD (1988) Stretch-activated ion channels modulate the resting membrane potential during early embryogenesis. Proc R Soc Lond [Biol] 235:95-102.

Misgeld U, Dietzel I (1989) Synaptic potentials in the rat neostriatum in dissociated embryonic cell culture. Brain Res 492:149-157.

Mishina M, Takai T, Imoto K, Noda M, Takahashi T, Numa S, Methfessel C. Sakmann B (1986) Molecular distinction between fetal and adult forms of muscle acetylcholine receptor. Nature 321:406-411.

Muller KJ, Nicholls JG, Stent GS (1981) Neurobiology of the leech. Cold Spring Harbor, NY: Cold Spring Harbor Laboratory.

Ohmori H, Sasaki S (1977) Development of neuromuscular transmission in a larval tunicate. J Physiol (Lond) 269:221-254.

Pellegrino M, Pellegrini M, Simoni A, Gargini C (1990) Stretch-activated cation channels with large unitary conductance in leech central neurons. Brain Res 525:322-326.

Perouansky M, Grantyn R (1988) Mechanisms of glutamate-excitation in visual neurons. In: Frontiers in excitatory amino acid research (Cavalheiro EA, Lehmann J, Turski L, eds), pp 167-170. New York: Liss.

Ready DF, Nicholls J (1979) Identified neurones isolated from leech CNS make selective connections in culture. Nature 281:67-69.

Ritchie AK, Fambrough DM (1975) Electrophysiological properties of the membrane and acetylcholine receptor in developing rat and chick myotubes. J Gen Physiol 66:327-355.

Rotman A, Daly JW, Creveling CR (1976) Oxygen-dependent reaction of 6-hydroxydopamine, 5,6-dihydroxytryptamine, and related compounds with proleins in vitro: a model for cytotoxicity. Mol Pharmacol 12:887-899.

Rude S (1969) Monoamine-containing neurons in the central nervous system and peripheral nerves of the leech, Hirudo medicinalis. J Comp Neurol 136:349-372.

Sakmann B, Brenner HR (1978) Change in synaptic channel gating during neuromuscular development. Nature 276:401 402 .
Sanchez-Armass S, Merz DC, Drapeau P (in press) Distinct receptors, second messengers and conductances underlying the dual responses to serotonin in an identified leech neurone. J Exp Biol, in press.

Schirrmacher K, Deitmer JW (1989) Membrane properties of identified embryonic nerve and glial cells of the leech central nervous system. J Comp Physiol A 164:645-653.

Schirrmacher K, Deitmer JW (1991) Sodium-and calcium-dependent excitability of embryonic leech ganglion cells in culture. J Exp Biol 155:435-454.

Schuetze SM, Role LW (1987) Developmental regulation of nicotinic acetylcholine receptors. Annu Rev Neurosci 10:403-457.

Silva NL, Mariani AP, Harrison NL, Barker JL (1988) 5,7-Dihydroxytryptamine identifies living dopaminergic neurons in mesencephalic cultures. Proc Natl Acad Sci USA 85:7346-7350.

Smith PA, Walker RJ (1975) Further studies on the action of various 5-hydroxytryptamine agonists and antagonists on the receptors of neurones from the leeches, Hirudo medicinalis and Haemopis sanguisuga. Comp Biochem Physiol 51C:195-203.

Smith PA, Fitzsimons JTR, Loker JE, Walker RJ (1975) 5-Hydroxytryptamine as a possible inhibitory neurotransmitter in the central nervous system of the leech, Haemopis sanguisuga. Comp Biochem Physiol 52C:65-73.

Streit J, Lux HD (1987) Voltage dependent calcium currents in PC12 growth cones and cells during NGF-induced cell growth. Pfluegers Arch 408:634-641.

Sunderland AJ, Leake LD, Walker RJ (1980) Evidence for an amine receptor on the Retzius cells of the leeches Hirudo medicinalis and Haemopis sanguisuga. Comp Biochem Physiol 67C:159-166.

Tang C-M, Dichter M, Morad M (1989) Quisqualate activates a rapidly inactivating high conductance ionic channel in hippocampal neurons. Science 243:1474-1477.

Walker RJ, Smith PA (1973) The ionic mechanism for 5-hydroxytryptamine inhibition on Retzius cells of the leech Hirudo medicinalis. Comp Biochem Physiol 45A:979-993.

Zar, JH (1974) Biostatistical analysis. Englewood Cliffs, NJ: PrenticeHall. 